\title{
A new species of the millipede genus Helicodesmus Golovatch, Geoffroy et VandenSpiegel, 2014, from southern Vietnam (Diplopoda: Polydesmida: Trichopolydesmidae)
}

\section{Новый вид диплопод рода Helicodesmus Golovatch, Geoffroy et VandenSpiegel, 2014, из Южного Вьетнама (Diplopoda: Polydesmida: Trichopolydesmidae)}

\section{Sergei I. Golovatch ${ }^{1}$, Didier VandenSpiegel ${ }^{2}$ С. И. Головач 1 , А. Ван ден Шпигель}

\footnotetext{
${ }^{1}$ Institute for Problems of Ecology and Evolution, Russian Academy of Sciences, Leninsky prospekt 33, Moscow 119071, Russia; E-mail: sgolovatch@yandex.ru

${ }^{1}$ Институт проблем экологии и эволюции РАН, Ленинский проспект 33, Москва 119071, Россия.

${ }^{2}$ Department of African Zoology, Royal Museum for Central Africa, Leuvensesteenweg 13, B-3080 Tervuren, Belgium; E-mail: didier.van.den.spiegel@africamuseum.be
}

KEY WORDS: Polydesmida, Helicodesmus, taxonomy, new species, Vietnam.

КЛЮЧЕВЫЕ СЛОВА: Polydesmida, Helicodesmus, таксономия, новый вид, Вьетнам.

ABSTRACT. Helicodesmus subcylindricus sp.n. is described from forest litter in southern Vietnam. It differs from the sole, and type, species $H$. anichkini Golovatch, Geoffroy et VandenSpiegel, 2014, also from southern Vietnam, by the subcylindrical body virtually devoid of paraterga, the shorter metatergal setae, the possible absence of ozopores from segment 18 and, above all, the less elaborate, albeit still fairly complex gonopods.

РЕЗЮМЕ. Из лесной подстилки в Южном Вьетнаме описан новый вид Helicodesmus subcylindricus sp.n. Он отличается от единственного, типового вида $H$. anichkini Golovatch, Geoffroy et VandenSpiegel, 2014, тоже из Южного Вьетнама, почти цилиндрическим телом, практически полностью лишённым паратергитов, более короткими тергальными щетинками, вероятным отсутствием пор защитных желёз на сегменте 18 и гораздо более простой, хотя и достаточно сложной структурой гоноподов.

\section{Introduction}

In the Oriental Region, the large, basically Northern Hemisphere family Trichopolydesmidae currently comprises 18 genera and 43 species [Golovatch et al., 2014]. One of the component genera is the monotypic Helicodesmus Golovatch, Geoffroy et VandenSpiegel, 2014, with the type species $H$. anichkini Golovatch, Geoffroy et VandenSpiegel, 2014, from southern Vietnam. The genus is characterized by 19 body segments $\left(\sigma^{7}, 7\right)$, the normal pore formula: $5,7,9-10,12-13,15-18$; the head devoid of modifications; the paraterga poorly-developed; the gonopod telopodites rather clearly exposed and trans- verse, but stout and remarkably complex, very strongly twisted, partly fimbriate/plumose distally, with several outgrowths of varying shapes; prefemoral (= densely setose) part about half the height of the telopodite, demarcated on the lateral (not medial!) side by an oblique seminal groove running further mesad onto a medioventral outgrowth of the acropodite to terminate distally, with neither a solenomere nor an accessory seminal chamber, nor a pulvillus [Golovatch et al., 2014].

The present paper puts on record a $2^{\text {nd }}$ congener, a new species also coming from southern Vietnam.

\section{Material and methods}

The material treated below was taken by Arnaud Faille (Bayerische Zoologische Staatssammlung, Munich, Germany), delivered to us for study by Louis Deharveng and Anne Bedos (Muséum national d'Histoire naturelle (MNHN), Paris, France).

SEM micrographs were taken using a JEOL JSM6480LV scanning electron microscope at the Muséum Royal de l'Afrique Centrale, Tervuren, Belgium(MRAC). After examination, SEM material was removed from stubs and returned to alcohol. Both types are deposited in the MNHN collection.

\section{Description}

Helicodesmus subcylindricus Golovatch et VandenSpiegel, sp.n. Figs 1-25

TYPE MATERIAL. Holotype $0^{7}$ (MNHN JC 379), Vietnam, Khanh Hoa Prov., Cat Lâm Distr., Suoi Cat community, Hon Ba 

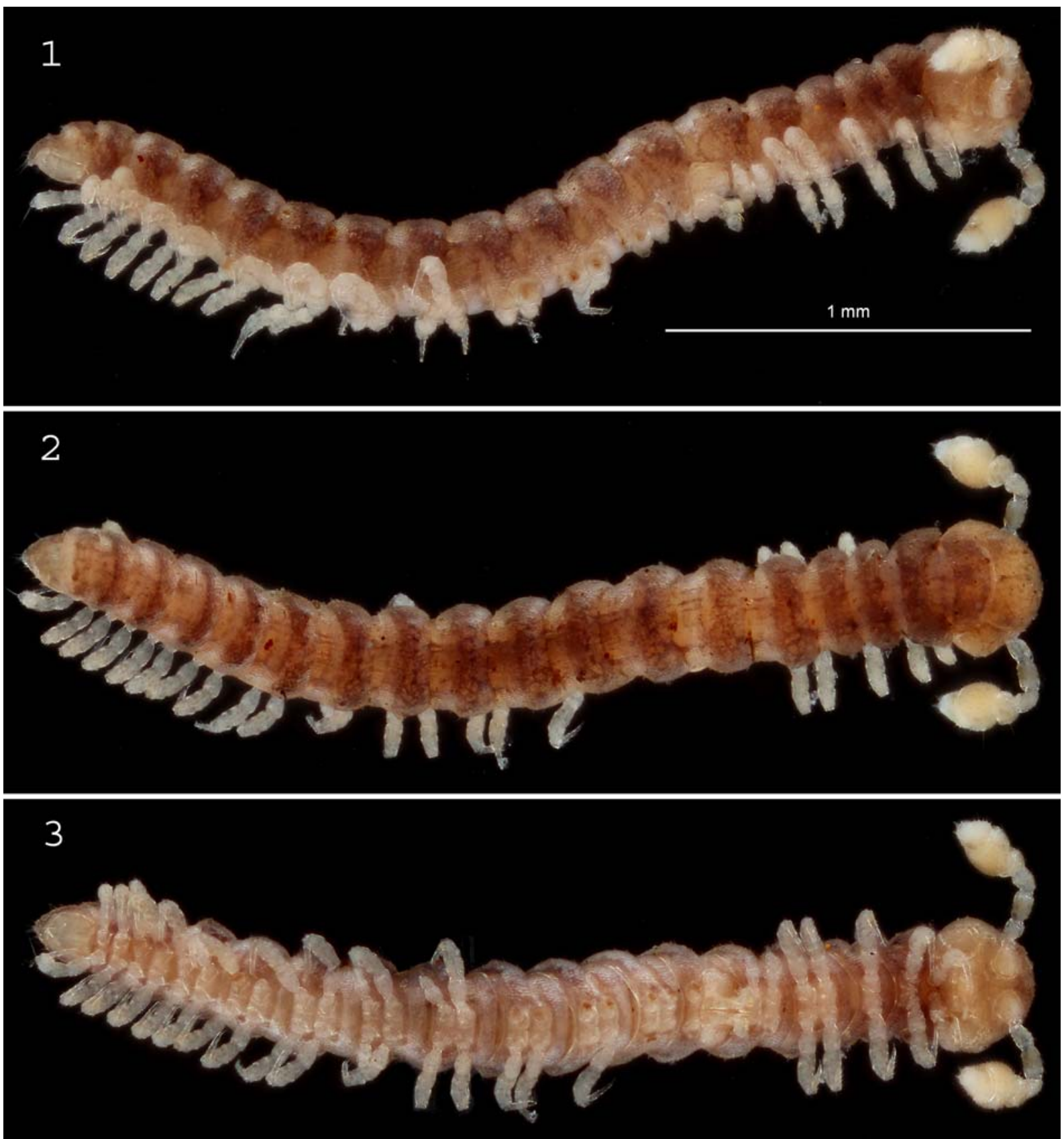

Figs 1-3. Habitus of Helicodesmus subcylindricus sp.n., O paratype: 1 - lateral; 2 - dorsal; 3 - ventral views. Pictures by J. Brecko. Scale bar: $1.0 \mathrm{~mm}$

Рис. 1-3. Общий вид Helicodesmus subcylindricus sp.n., паратип о: 1 - сбоку; 2 - сверху; 3 - снизу. Фотографии J. Brecko. Масштаб: 1,0 мм.

Nature Reserve, road to Alexandre Yersin's monument in Hon Ba, 1350-1550 m a.s.1., mountain tropical rainforest, litter, Berlese extraction after Winkler extraction, 14.XI.2013, leg. A. Faille (Vn03186). Paratype: $1 \sigma^{7}$ (SEM), same locality, together with holotype.

NAME. To emphasize the subcylindrical body virtually devoid of paraterga.
DIAGNOSIS. Differs from the only congener, the type species $H$. anichkini, also from southern Vietnam, by the subcylindrical body virtually devoid of paraterga, the shorter metatergal setae, the possible absence of ozopores from segment 18 and, above all, the less elaborate, albeit still fairly complex gonopods [cf. Golovatch et al., 2014].

Рис. 4-17. SEM-микрофотографии Helicodesmus subcylindricus sp.n., паратип О’: 4 - общий вид; 5, 8, 11 - передняя часть тела; 6, 9, 12 - среднетуловищные сегменты; 7, 10, 13 - задняя часть тела; 14 - антенна; 15 - тергальная щетинка на шишечке; 16 текстура тергита и лимбус; 17 - нога; 4-7, 14-15 - сбоку; 8-10, 16 - сверху; 11-13 - снизу; 17 - спереди. Масштаб: 0,5 (4), 0,1 $(5,6,8,9,11,12), 0,05(7,10,13,14), 0,02(17), 0,01$ мм $(15,16)$. 

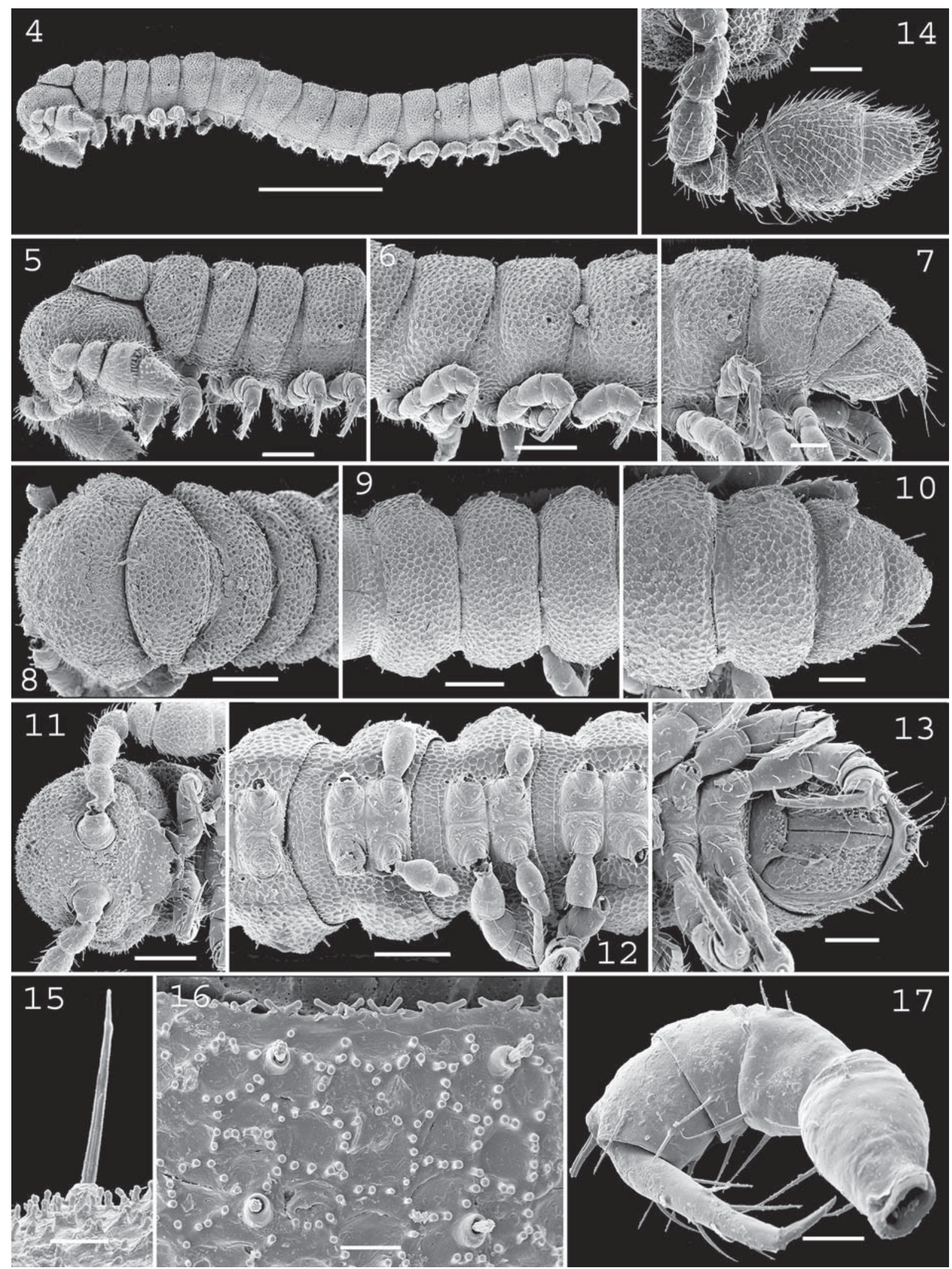

Figs 4-17. SEM micrographs of Helicodesmus subcylindricus sp.n., $\bigcirc^{7}$ paratype: 4 - habitus; 5, 8, 11 - anterior part of body; 6, 9 , 12 - midbody segments; 7, 10,13 - posterior part of body; 14 - antenna; 15 - tergal seta on knob; 16 - tergal texture and limbus; 17 - leg; 4-7, 14-15 - lateral view; 8-10, 16 - dorsal view; 11-13 - ventral view; 17 - anterior view. Scale bars: 0.5 (4), 0.1 (5, 6, $8,9,11,12), 0.05(7,10,13,14), 0.02(17), 0.01 \mathrm{~mm}(15,16)$. 

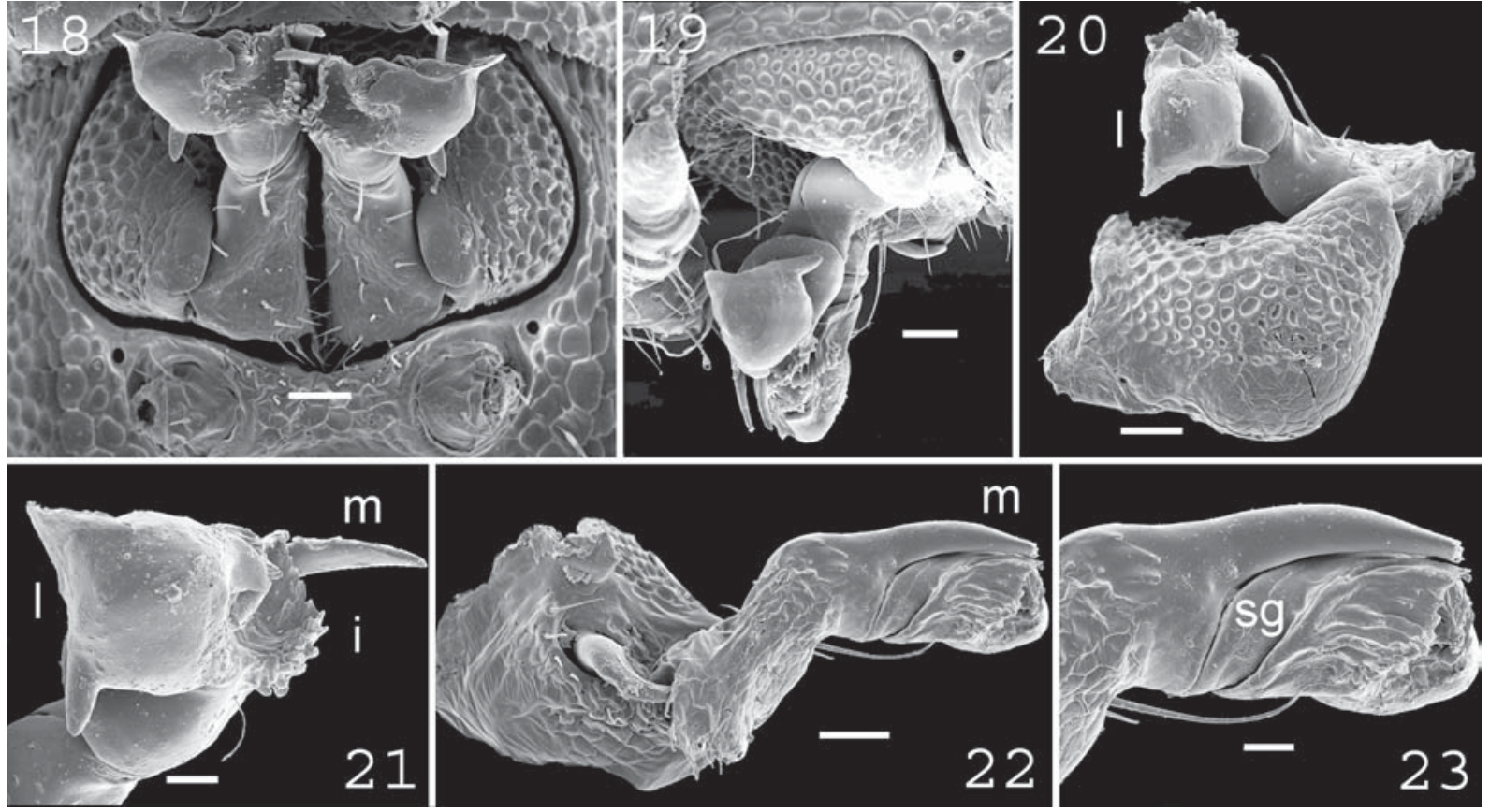

Figs 18-23. SEM micrographs of Helicodesmus subcylindricus sp.n., o paratype: 18-19 — both gonopods in situ; 20-21 - right gonopod; 22-23 - left gonopod and its distal part, respectively (tip of branch $\mathbf{m}$ broken off); 18, 21 — ventral view; 19-20 - lateral view; 22-23 - mesal view. Scale bars: $0.02(18-20,22), 0.01 \mathrm{~mm}(21,23)$. Designations explained in text.

Рис. 18-23. SEM-микрофотографии Helicodesmus subcylindricus sp.n., паратип О7: 18-19 - оба гонопода на месте; 20-21 правый гонопод; 22-23 - соответственно левый гонопод и его дистальная часть; 18, 21 - снизу; 19-20 - сбоку; 22-23 - изнутри. Масштаб: 0,02 (18-20, 22), 0,01 мм $(21,23)$. Объяснение обозначений в тексте.

DESCRIPTION. Length of adults ca $3.0 \mathrm{~mm}$, width of midbody pro- and metazonae 0.25 and $0.3 \mathrm{~mm}$, respectively $\left(\mathrm{O}^{7}\right)$. Coloration in alcohol rather uniformly castaneous marbled brown, only antennae, venter and legs light yellowish to yellowish brown (Figs 1-3).

Body with 19 segments $\left(\bigcirc^{\top}\right)$, subcylindrical, slightly moniliform, virtually devoid of paraterga. Tegument dull, texture delicately micro-alveolate, with abundant microvilli arranged in a polygonal meshwork, but devoid of a cerategument (Figs 4 13, 15-16). Head without modifications, cranium regularly and strongly convex, mostly densely pilose, with only a faint impression behind clypeolabrum; interantennal isthmus nearly as wide as diameter of antennal socket (Figs 5, 8,11 ). Antennae very short, strongly claviform, subgeniculate between antennomeres 4 and 5 , the latter much smaller than largest $6^{\text {th }}$; both $5^{\text {th }}$ and, especially, $6^{\text {th }}$ with a usual, tight, distodorsal group of numerous bacilliform sensilla (Figs 5, 14).

In width, collum $<$ segment $3=4<2<$ head $=5=16\left(\sigma^{7}\right)$, thereafter body gradually tapering towards telson (Figs 2,8 10). Small rounded bulges instead of paraterga, these bulges being a little larger in pore-bearing segments, set at about 1 / 2 of body height (Figs 4-10). Pore formula normal: 5, 7, 9$10,12-13,15-17$, but ozopores seem to be absent from segment 18 (Fig. 7). Ozopores fully lateral, small and rather obscure, mostly lying at about caudal $1 / 3$ of metazonite's length, shifted increasingly closer to caudal margin only in posterior half of body (Figs 4-7). Collum biconvex, rather narrowly rounded laterally on both sides, with 3 transverse rows of very short setae (Figs 4-5, 8). Each following metatergum with $3+3$ rather vague, similarly short, slightly blunted to subacuminate, sometimes subclavate, longitudinally ribbed setae arranged in 3 transverse regular rows and borne on minute knobs; sulci between the rows absent (Figs 4-10). Stricture between pro- and metazonae rather deep and narrow, scaly like rear part of prozonae (Figs 4-10, 12). Limbus very fine, very delicately and sparsely microcrenulate (Figs 9-10, 12-13, 16). Pleurosternal carinae absent (Figs 5-7). Epiproct short, conical, truncate, directed caudoventrally; pre-apical papillae large (Figs 7, 10, 13). Hypoproct subtrapeziform, caudal setigerous papillae well-developed and clearly separated (Fig. 13).

Sterna without modifications, rather broad and sparsely setose. Legs short, ca 1.0-1.1 times as long as midbody height $\left(O^{7}\right)$; prefemora, femora, postfemora and tibiae clearly incrassate, tarsi longest, slender, sphaerotrichomes missing; claws simple, slightly curved (Figs $4-7,13,17$ ); $\sigma^{7}$ coxae 2 with very short, membranous, cylindrical gonapophyses.

Gonopod aperture transversely oblong-oval, slightly subcordate, taking up most of ventral part of metazonite 7 (Fig. 18). Gonopods (Figs 18-25) rather complex, with globose, micro-alveolate, medially fused coxae carrying a few setae on ventral face and a normal cannula mesally. Telopodites mostly exposed, in situ held parallel to each other, nearly contiguous medially, moderately curved ventrad, each tripartite and very strongly twisted, with a rather large, densely setose prefemoral part and a similarly long, transverse and far more complex acropodite. The latter consisting of a long, spiniform, anteromedian process (m), a shorter, distally cupshaped, apically densely denticulate, inner branch (i) and a similarly short, squarish, lateral branch (I). Seminal groove (sg) originating medially, but immediately moving laterad to again return mesad at about midway, thus making a $180^{\circ}$ loop; neither a solenomere nor a hairy pulvillus, sg ending up subapically at bottom of $\mathbf{i}$ cup. 


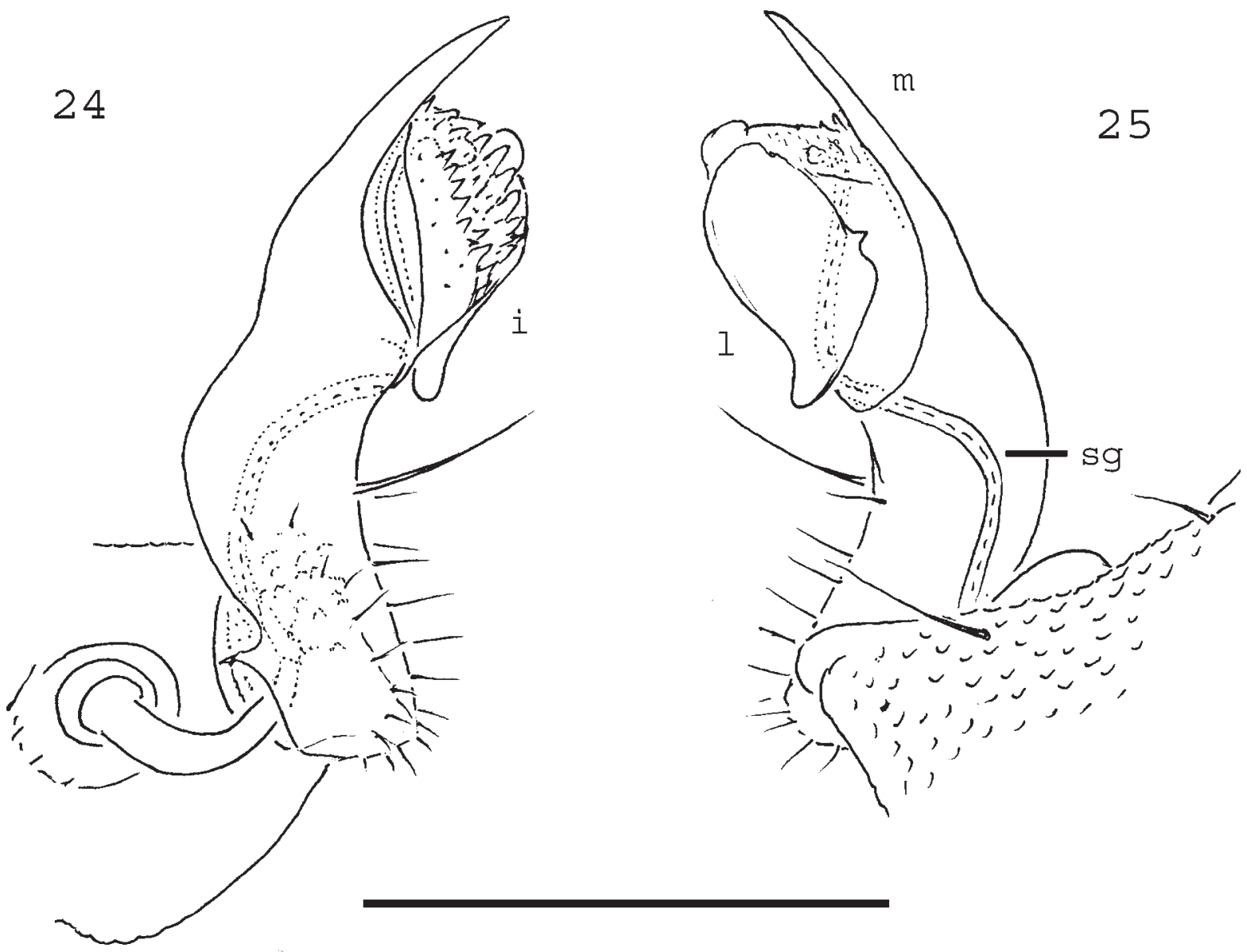

Figs 24-25. Left gonopod of Helicodesmus subcylindricus sp.n., $\mathrm{O}^{7}$ holotype, mesal and lateral views, respectively. Scale bar: $0.1 \mathrm{~mm}$. Designations explained in text.

Рис. 24-25. Левый гонопод Helicodesmus subcylindricus sp.n., голотип О’, соответственно изнутри и сбоку. Масштаб: 0,1 мм. Объяснение обозначений в тексте.

REMARKS. The gonopod structure of $H$. anichkini is extremely elaborate, with as many as five apical branches delimited [Golovatch et al., 2014]. In H, subcylindricus sp.n., the apical half of the gonotelopodite is more compact and simple, with only three branches distinguished: $\mathbf{i}, \mathbf{I}$ and $\mathbf{m}$. Branch $\mathbf{i}$ is cup-shaped, fringed and microdenticulate apically, resembling the cup-shaped structure observed between branches $\mathbf{m}$ and $\mathbf{I}$ in $H$. anichkini. What brings both species together, however, is the remarkably strongly twisted gonopod telopodite, in which the seminal groove makes a $180^{\circ}$ loop before ending up subapically near the base of the mesal branch.

ACKNOWLEDGEMENTS. Special thanks go to Louis Deharveng and Anne Bedos (both MNHN) and Arnaud Faille (ZSM) for the provision of the material treated above. Jonathan Brecko (MRAC) very skillfully took the pictures. The 2013 field work in the Hon Ba Nature Reserve in Vietnam was funded by the LabEx BCDiv (Diversités Biologiques et Culturelles) through the MNHN, Paris (grant of the Agence Nationale de la Recherche for the LabEx ANR-10-LABX0003-BCDiv, in the framework of the programme « Investissements d'Avenir » (ref. $n^{\circ}$ ANR-11-IDEX-0004-02), the trip of Arnaud Faille was supported by the German Research Foundation (DFG project FA1-42F/1-1). The field trip to Hon Ba was made possible thanks to Truong Quang Tam (Institute of Tropical Biology, Ho Chi Minh City) and the staff of the Hon Ba Nature Reserve.

\section{Reference}

Golovatch S.I., Geoffroy J.-J., VandenSpiegel D. 2014. Review of the millipede family Trichopolydesmidae in the Oriental realm (Diplopoda, Polydesmida), with descriptions of new genera and species // ZooKeys. Vol.414. P.19-65. 